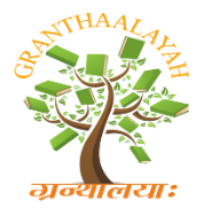

\author{
INTERNATIONAL JOURNAL OF RESEARCH \\ GRANTHAALAYAH \\ A knowledge Repository
}

Science

\title{
SASAKAWA TECHNOLOGY A PANACEA TO MAIZE YIELD IMPROVEMENT AND MEETING THE VAGARIES OF CLIMATE CHALLENGE IN MUBI
}

\author{
Mohammed D. Toungos *1 \\ ${ }^{*}$ Ph.D., Crop Science Department, Adamawa State University Mubi, Adamawa State of Nigeria
}

\begin{abstract}
This study determines the efficacy of Sasakawa technology to maize yield improvement and meeting the demand of the populace in terms of food crop production at the time of unpredictable weather conditions in Mubi. The field trials were conducted during the 2017 cropping season at the teaching and research farm of the Faculty of Agriculture, Adamawa state University Mubi to evaluate the effect of Sasakawa Technology as a panacea to maize yield improvement and meeting the vagaries of climate change in Mubi. Mubi, located in the Northern Guinea Savannah of Nigeria. Mubi is situated between latitude 10010 " and 10030 " North of the Equator and between longitude 13010 and 13030 " E of the Greenwich meridian and at an altitude of $696 \mathrm{~m}$ above mean sea level (MSL). Extra early white (EEW) variety of maize was obtained from Farm office of the University, were sown at three different sowing dates 19th July, 29th July and 8th August, 2018. There was a large yield difference between the Sasakawa Technology of maize production and local farmers' output in Mubi, despite the limited opportunities to sustainability and increase in the productivity of the crop in order to adapt to vagaries of climate change. Yields recorded during the three sowing dates were $2,967 \mathrm{~kg} / \mathrm{ha}, 2,930 \mathrm{~kg} / \mathrm{ha}$ and $2,921 \mathrm{~kg} / \mathrm{ha}$ while on the neighboring farmer's field was $1,897 \mathrm{~kg} / \mathrm{ha}$. It indicated that, the Sasakawa technology used in terms of spacing of $25 \mathrm{~cm} \times 25 \mathrm{~cm}$ between plants and $75 \mathrm{~cm} \times 75 \mathrm{~cm}$ between rows, single seed per stand and appropriate fertilizer application increased maize yield more than the neighboring farmers fields. The Sasakawa technology recorded mostly two cobs per stand, longer cobs mean lengths with maximum grain filled and the grains were significantly bigger when compared to the farmer's fields. Even though some critics argue that, Sasakawa Global 2000 technology deals with high-external-input technologies (HEIT) which are too costly to some farmers, but the out - put out weights the input in terms of yields, economic returns and also sustained the vagaries of climatic effects due to timely sowing and maintenance of the Sasakawa technology techniques. To boost maize production in Mubi and at this time of unpredictable climate and its effects, the Sasakawa technology is recommended to be adopted by the farmers.
\end{abstract}

Keywords: Sasakawa; Technology; Vagaries; Extra Early White; High-External-Input Technologies.

Cite This Article: Mohammed D. Toungos. (2018). "SASAKAWA TECHNOLOGY A PANACEA TO MAIZE YIELD IMPROVEMENT AND MEETING THE VAGARIES OF 
CLIMATE CHALLENGE IN MUBI.” International Journal of Research - Granthaalayah, 6(10), 194-201. https://doi.org/10.29121/granthaalayah.v6.i10.2018.1184.

\section{Introduction}

Maize which is popularly known as "Corn" is one of the most versatile emerging cereal cash crops having wider adaptability under variety of climatic conditions. It is called the queen of cereals globally. The crop can be grown throughout the year in Northern Nigeria and more especially in Mubi, the study area which is the commercial nerve center of Adamawa State, Nigeria. Maize is also one of the three most important cereals grown in Nigeria along with sorghum and millet (USAID, 2010). Being a priority crop under the flagship agricultural programs of the Nigerian government since 2012. Maize is also the most important cereal crop in Sub-Saharan Africa, with rice and wheat; maize, rice and wheat, are one of the three most important cereal crops in the World (FAO, 2006).

Maize (Zea mays L.) is a member of the grass family (Poacea). It originated from South and Central America and later introduced to West Africa by the Portuguese in the $10^{\text {th }}$ Century (Olaniyi and Adewale, 2012). Maize is the staple food in Sub - Saharan Africa for an estimated 50\% of the population (FAO 2006).

Maize crop requires adequate soil fertility for high productivity in which it requires relatively higher Nitrogen (N), Phosphorus (P) and Potassium (K) than other elements as opined by Ibrahim and Isa (2012). Idachaba, (2006), also reported that, maize output of countries correlate strongly and positively with fertilizer consumption. Moreover, maize respond favorably to fertilizer especially in the Savannah, where soils are generally low in native fertility (Hussain et al, 2004). However, among the three most essential nutrients for proper growth and performance of maize, nitrogen and phosphorus are the most limiting in the Savannah soils, this is not unconnected with the vagaries of weather in the area.

Despite the importance and increase in number of farmers to maize production, yield per hectare is still relatively low in the study area due to the unpredictable rains and heavy floods when it occurs. This is in addition to the low organic matter content, low CEC, low water holding capacity and low fertility levels. In order to increase yield during the time of the vagaries of climatic change, coupled with the low yield experienced by the farmers the adoptation of the Sasakawa technology is one of the best options in boosting yield production in Mubi and the environs. Sasakawa technology takes into consideration all the agronomic activities involved in maintaining and obtaining higher yield on small area under intensive and prudent management within the shortest possible time.

Climate variability and extremes are already negatively undermining production of major crops in the regions and, without adaptation and practicing the appropriate techniques and technologies, this is expected to worsen as temperatures increase and become more extreme. In many areas, climate extremes have increased in number and intensity, particularly where average temperatures are shifting upwards: very hot days are becoming more frequent and the hottest days are becoming hotter, this leads to lower crop yields and other consequences that undermine food security, FAO (2018). In addition to increasing temperatures and changes in rainfall, the nature of rainy seasons 
is also changing, specifically the timing of seasonal climate events. The number of extreme climate-related disasters, including extreme heat, droughts, floods and storms, has doubled since the early 1990s, with an average of 213 of these events occurring every year during the period of 1990-2016. This is also prevalent in the sudano-sahelian zone, where the study area is located. These harms agricultural productivity contributing to shortfalls in food availability, with knockon effects causing food price hikes and income losses that reduce people's access to food. (FAO, 2016).

Food security and nutrition indicators can clearly be associated with an extreme climate event, such as a severe drought, that critically challenges agriculture and food production. Timing of planting and having early maturing variety with proper management can ameliorate the poor yields been experienced by local farmers in Mubi area and the surrounding environments. Of all natural hazards, floods, droughts and storms affect food production the most; especially in Mubi where almost all the trees have been cut down without replacements. Drought, in particular, causes more than 80 percent of the total damage and losses in agriculture, especially for the livestock and crop production subsectors, FAO (2018). If a drought is severe and widespread enough, it can potentially affect national food availability and access, as well as nutrition, thus magnifying the prevalence of undernourishment (PoU) nationally. The majority of people most vulnerable to climate shocks and natural hazards are the world's 2.5 billion small-scale farmers, herders, fishers and forest-dependent communities, who derive their food and income from renewable natural resources. Climate variability and extremes have the strongest direct impact on food availability, given the sensitivity of agriculture to climate and the primary role of the sector as a source of food and livelihoods for the rural poor. Hence the use of Sasakawa technology in maize production in order to meet up the demand of the over growing population in the study area becomes necessary. Climate variability and extremes are undermining all dimensions of food security: food availability (with losses in productivity that undermine food production and increase food imports); food access (causing spikes in food prices and volatility, especially following climate extremes, income loss for those who depend on agriculture); food utilization and food safety (worsened or reduced dietary consumption, reduced quality and safety of food because of crop contamination, outbreaks of pests and diseases because of rainfall intensity or changes in temperature. Climate variability also puts all aspects of food security at risk: the amount of food produced, people's access to it, people's ability to absorb nutrients and the safety of the food itself are all affected. Direct and indirect climate-driven impacts also have a cumulative effect, leading to a downward spiral of increased food insecurity and malnutrition. But with proper technological management, the effects will be brought to the barest minimum.

As stated, an obvious impact is that climate variability and extremes negatively affect agricultural productivity, in terms of changes in crop yields (the amount of agricultural production harvested per unit of land area), cropping areas (area planted or harvested), or cropping intensity (number of crops grown within a year).In addition, climate variability and extremes also affect food imports as countries try to compensate for domestic production losses. The impacts on production will inevitably translate into loss of income for people whose livelihoods depend on agriculture and natural resources, reducing their ability to access food. Another factor is spikes in food prices and volatility follow climate extremes. Climate anomalies, and in particular extreme events, alter agricultural yields, production and stocks. Impact of high food price volatility pose a major threat to food access, especially in low- and middle-income farmers. The impact of price spikes and 
volatility not only falls heaviest on the urban poor, but also of small-scale food producers, agriculture laborers and the rural poor who are net food buyers.

Climate variability and extremes also lead to income loss for those whose livelihoods depend on agriculture and natural resources, which then negatively impact food access as households have less resources to purchase food. There is also evidence that climate shocks not only affect the level of income, but affect also the variability of incomes, FAO (2018). More erratic rainfall and higher temperatures along with other extreme events affect the quality and safety of food. Changing climate conditions and extremes such as temperature and humidity can lead to increased contamination of water and food. Climate-related disasters create and sustain poverty, contributing to increased food insecurity and malnutrition as well as current and future vulnerability to climate extremes. They also have impacts on livelihoods and livelihoods assets - especially of the poor contributing to greater risk of food insecurity and malnutrition. Prolonged or recurrent climate extremes lead to diminished coping capacity, loss of livelihoods, distress migration and destitution.

\section{Materials and Method}

This research was conducted at the Teaching and Research Farm of the Department of Crop Science, Faculty of Agriculture, Adamawa State University, Mubi. It was conducted under rainfed condition cropping season. Mubi located in the Northern Guinea Savanna of Nigeria is situated between latitude $10^{\circ} 10^{\prime \prime}$ and $10^{\circ} 30^{\prime \prime}$ North of the Equator and between longitude $13^{\circ} 10^{\prime \prime}$ and $13^{\circ}$ 30" East of Greenwich meridian and at an altitude of $696 \mathrm{~m}$ above mean sea level (MSL). The annual mean rainfall of Mubi is $900 \mathrm{~mm}$, and a minimum temperature of $18^{\circ} \mathrm{C}$ during harm tan period and $40^{\circ} \mathrm{C}$ as maximum in April (Adebayo, 1990). It has a total land area of 4,728km2.

\subsection{Experimental Procedure}

Crop Variety: Extra early white (EEW) variety of maize was obtained from Farm office of the University, were sown at one seed per hole at the depth of $2-3 \mathrm{~cm}$ on a levelled plot with a spacing of $25 \mathrm{~cm}$ by $25 \mathrm{~cm}$ and $75 \mathrm{~cm}$ by $75 \mathrm{~cm}$.

Sowing and Fertilizer Application: Seeds were sown at the rate of one seed per hill at the depth of $2.3 \mathrm{~cm}$ at a spacing of $23 \mathrm{~cm} \times 23 \mathrm{~cm}$ and $75 \mathrm{~cm} \times 75 \mathrm{~cm}$. Gabs were filled after 10 days of sowing with the remaining seeds. An inorganic compound fertilizer NPK 20:10:10 was applied at 8gram per hill during sowing and later followed by Urea as second dose with 2grams per plant during 3 $-4^{\text {th }}$ weeks after sowing by proper burying the fertilizer between the plants as recommended.

Gap Filling: The empty spaces were supplied 10 days after sowing using the remaining seeds Weed Control: weeds were hoed and hand pulled. The site was maintained throughout the experimental period.

\subsection{Treatments}

Data Collected: The following parameters were recorded during the agronomic activities. Plant height $(\mathrm{cm})$; number of leaves; Leaf area; number of cobs per plant; cob length; panicle length $(\mathrm{cm})$; weight of 1000-grain $(\mathrm{g})$ and yield per hectare $(\mathrm{kg})$. 
Plant Height: The plant height in a quadrat was taken randomly and measured using measuring graduated tape from the base of the plant to the last flag leaf at $3^{\text {rd }}, 5^{\text {th }}$ and $7^{\text {th }}$ weeks after sowing and results recorded in $\mathrm{cm}$.

Number of leaves: Number of leaves were selected randomly in a plot and counted and results recorded.

Number of Cobs per Plant: The highest number of cobs per plant in the quadrat were recorded. Cob length: The cobs highest cob lengths in the quadrat with productive yield were measured using measuring tape and results recorded.

Leaf Area: The selected leaf area was measured using the leaf length and maximum width and multiplied by a factor 0.70 i.e. maize leaf calibration factor. The results were taken and recorded.

Panicle Length: The panicle length was measured using a $30 \mathrm{~cm}$ ruler and results recorded accordingly.

Weight of 1000-grain (g): The grain weight of 1000 seeds from each quadrat $(10 \mathrm{~m} \times 10 \mathrm{~m})$ was taken and weighted in grams using chemical balance.

Data Analysis: Data collected were analyzed and results presented in percentages performance over the farmer's sample farm.

Yield per Hectare: Harvesting was done when the crop matured. That is when the kernels reached hard dough stage and the black layer was shown at the point of attachment of the grain to the cob. The cobs were picked up and dried to a safer moisture content and weight using weighing balance. The yield per hectare was also calculated based on quadrat harvested and recorded in $\mathrm{kg} / \mathrm{ha}$.

\section{Results and Discussion}

The results indicated that, the major components in maize productions such as, cob weight, number of cobs per plant and grain size expressed as 1000 grain weight were all observed to be higher in the Sasakawa technology trial plots as compared to the farmer's plots. The yield per quadrat were also recorded as $2,967 \mathrm{~kg} / \mathrm{ha} ; 2,930 \mathrm{~kg} / \mathrm{ha}$ and $2,921 \mathrm{~kg} / \mathrm{ha}$ respectively for $1^{\text {st }}, 2^{\text {nd }}$, and $3^{\text {rd }}$ sowing dates respectively, while the neighboring farmer's plot got $1,897 \mathrm{~kg} / \mathrm{ha}$ to $2060 \mathrm{~kg} / \mathrm{ha}$ at best sites with same area with the Sasakawa technology.

The average plants height indicates that, Sasakawa technology exhibits higher plants heights during the three sowing dates at 3 weeks after sowing (WAS), with the $2^{\text {nd }}$ sowing date recorded the mean highest plant height of $41.66 \mathrm{~cm}$, while the neighboring famer's field recorded $35.43 \mathrm{~cm}$. This trend followed at both $5^{\text {th }}$ and $7^{\text {th }}$ WAS as can be seen on Table 1 . The results is also in agreement with the work of Valencia, J and Mohammed, B (2011), Sasakawa technology out performed famers yield in terms of plant height and number of cobs per plant during their experimental trials. The leaves area was also observed to be larger in the trial area when compared with the farmer's farm.

Table 1: Sasakawa technology as compared to farmer's plot in terms of plant height.

\begin{tabular}{|l|l|l|l|}
\hline Treatments & $\begin{array}{l}\text { Plant height }(\mathbf{c m}) \\
\mathbf{3}^{\text {rd }} \text { weeks) }\end{array}$ & $\begin{array}{l}\text { Plant height }(\mathbf{c m}) \\
\left(\mathbf{5}^{\text {th }} \text { weeks }\right)\end{array}$ & $\begin{array}{l}\text { Plant height }(\mathbf{c m}) \\
\left.\mathbf{7}^{\text {th }} \text { weeks }\right)\end{array}$ \\
\hline Sasakawa technology & & & \\
$\mathbf{1}^{\text {st }}$ sowing date & 41.50 & 83.50 & 123.72 \\
$\mathbf{2}^{\text {nd }}$ sowing date & 41.66 & 84.50 & 122.65 \\
$\mathbf{3}^{\text {rd }}$ sowing date & 40.65 & 83.44 & 122.07 \\
\hline
\end{tabular}




\begin{tabular}{|l|l|l|l|}
\hline $\begin{array}{l}\text { Farmer's plot. } \\
\text { Mean percentage performance. }\end{array}$ & 35.43 & 36.70 & 194.25 \\
\hline
\end{tabular}

The results in Table 2 indicates that, most of the plants in Sasakawa technology trials produced two cobs per stand while that of the next farmer's farm produced one cob on most plants. In terms of performance, the Sasakawa Technology outperformed 100\% to that of the farmer's. Mean cobs length was also longer in the Sasakawa technology at the three sowing dates with $25 \mathrm{~cm}, 24 \mathrm{~cm}$ and $23.40 \mathrm{~cm}$ respectively, while the farmer's field recorded and average height of $18 \mathrm{~cm}$.

Table 2: Sasakawa technology as compared to farmer's plot in terms of cobs/plant and plant length.

\begin{tabular}{|l|l|l|}
\hline Treatments & Cobs/plant & Cobs length $(\mathbf{c m})$. \\
\hline Sasakawa technology & & \\
$\mathbf{1}^{\text {st }}$ sowing date & 2 & $25.00 \mathrm{~cm}$ \\
$\mathbf{2}^{\text {nd }}$ sowing date & 2 & $24.00 \mathrm{~cm}$ \\
$\mathbf{3}^{\text {rd }}$ sowing date & 2 & $23.40 \mathrm{~cm}$ \\
Farmers plot. & 1 & $18.00 \mathrm{~cm}$ \\
Mean percentage performance. & 100 & \\
\hline
\end{tabular}

The results in Table 3 also indicates that, the Sasakawa technology out performed the farmer's field in terms of cob weight during the three sowing dates with $1.3 \mathrm{~kg}, 1.3 \mathrm{~kg}$ and $1.2 \mathrm{~kg}$ while the farmer's field recorded $0.8 \mathrm{~kg}$ cob weight. There were significant difference in terms of yield per hectare, during the three sowing dates as compared with the farmer's yield. The results indicated that, $1^{\text {st }}$ sowing date recorded the highest yield per hectare with $2,967 \mathrm{~kg}$; closely followed by $2^{\text {nd }}$ and $3^{\text {rd }}$ sowing dates with $2,930 \mathrm{~kg} /$ ha and $2,921 \mathrm{~kg} /$ ha. The farmer's field recorded a yield of $1,897 \mathrm{~kg} / \mathrm{ha}$. The results are in agreement with Sasakawa Global 2000 on maize yield using Sasakwa technology as compared to famer's plots.

Table 3: Sasakawa technology as compared to farmer's plot in terms of cob weight and grain

\begin{tabular}{|c|c|c|}
\hline & Cobs weight (kg) & Yield (kg/ha). \\
\hline $\begin{array}{l}\text { Sasakawa technology } \\
1^{\text {st }} \text { sowing date } \\
2^{\text {nd }} \text { sowing date } \\
3^{\text {rd }} \text { sowing date } \\
\text { Farmers plot. } \\
\text { Mean percentage performance. }\end{array}$ & $\begin{array}{l}1.3 \mathrm{~kg} \\
1.3 \mathrm{~kg} \\
1.2 \mathrm{~kg} \\
0.8 \mathrm{~kg}\end{array}$ & $\begin{array}{l}2,967 \mathrm{~kg} . \mathrm{ha} \\
2,930 \mathrm{~kg} / \mathrm{ha} \\
2,921 \mathrm{~kg} / \mathrm{ha} \\
1,897 \mathrm{~kg} / \mathrm{ha}\end{array}$ \\
\hline
\end{tabular}

\section{Conclusion and Recommendation}

The Sasakawa technology, produce higher cobs and mostly two cobs per stand, higher grains per cob, lager cob size and higher yield than the neighboring famers plots. The low output on farmer's plots might not be unconnected, due to their inability to adopt the Sasakawa technology. High loading was also observed to be a serious factor on famer's plots; it might also be due to not adopting proper management practices of maize production in an area affected by climatic change. 
As stated by FAO (2018), addressing climate variability and extremes and their impact on food security and nutrition requires a focus on resilience. Context-specific interventions aimed at anticipating, limiting, and adapting to the effects of climate variability and extremes and building the resilience of livelihoods, food systems and nutrition to climatic shocks and stresses.

Scaled-up actions across sectors are urgently needed to strengthen the resilience of livelihoods and food systems to climate variability and extremes. Such actions should take place through integrated disaster risk reduction and management and climate change adaptation policies, programmes and practices with short-, medium- and long-term vision.

Implementation of climate resilience policies and programmes means adopting and refitting tools and interventions such as: risk monitoring and early warning systems; emergency preparedness and response; vulnerability reduction measures; shock-responsive social protection, risk transfers and forecast-based financing; and strong risk governance structures in the environment-foodhealth system nexus.

Solutions require increased partnerships, enhanced risk management capacities and multi-year, predictable large-scale funding of disaster risk reduction and management and climate change adaption policies, programmes and practices. This can only be achieved by adopting the Sasakawa technology and using improved seed in order to boost maize production to meet up with the increasing population explosion and the vagaries of climate change in the study are and beyond. The Sasakawa technology and improved seed varieties is therefore, recommended in the study area in order to meet up with the demand of the increasing population coupled with the vagaries of climate change experiencing in the area.

\section{References}

[1] Adebayo, A.A. (1990). Climate11. Rainfall. In: Adamawa State in Maps. Adebayo, A.A. and Tukur, A. L. (eds.) Paraclate Publishers Yola. Pp $23-26$.

[2] F.A.O (2018). State of Food Security and Nutrition in the World. www.fao.org-of-foodnutrition/en/. Retrieved $25^{\text {th }}$ October, 2018.

[3] F.A.O STAT., (2006). Food and Agricultural Organization Statistics. www.fao.org. Retrieved October, 2018.

[4] Hussaini, M.A., Mohammed, S.G and Jibrin, J.M (2004). Effects of different levels of Nitrogen and Phosphorus on the performance of Maize (Zea mays L.) Under varing irrigation regimes in the Sudan Savannah Zone. Journal of Agriculture. 14:85-91.

[5] Ibrahim, H. and Isa, H.M. (2012). Growth attributes of Maize (Zea Mays L.) Varieties as influenced by different rates of fertilizer.

[6] Idachaba, F.S. (2006). An overview of Nigeria's fertilizer Sector, Paper presented at the National Fertilizer Policy Workshop, Agricultural Society of Nigeria Proceedings, $46^{\text {th }}$ Annual Conference, Held at Kano, Nigeria, November $5^{\text {th }}-9^{\text {th }}, 2012$.

[7] Olaniyi, O.A. and Adewale, J.G. (2012). Information on Maize Production among Rural Youths. A Solution to Sustainable Food Production in Nigeria. University of Technology Oyo,

[8] Nigeria. Library Philosophy and Practice. Available: http://www.webpages.uihaho.edu/htmbolin/Olaniyi-adewale.html. Retrieved $24^{\text {th }}$ October, 2018.

[9] Sasakawa Global 2000. A simplified guide for crop production in Nigeria. 2010; 9-12. Valencia J, Mohammed B. Maize crop production guide. Commercial Agriculture Development project (World Bank Assisted) and Sasakawa Global 2000; 2011. 
[10] USAID, 2010: United States Agency for International Development (USAID), 2010. Packages of practices for maize production. Prepared by USAID/Maximizing Agricultural Revenues and Key Enterprises in Targeted Sites (MARKETS).

*Corresponding author.

E-mail address: dahiru.toungos@ gmail.com/toungosm@ adsu.edu.ng 